\title{
Profitabilitas, Peluang Pertumbuhan, Modal Kerja Bersih Serta Dampaknya Terhadap Kebijakan Penahanan Kas Pada Sektor Perbankan Yang Terdaftar Di Bursa Efek Indonesia
}

\author{
Azimah Dianah ${ }^{\mathrm{a}^{*}}$, Ana Fitria ${ }^{\mathrm{b}^{*}}$, Abrar Amri ${ }^{\mathrm{c}^{*}}$, Rina Desiana $\mathrm{d}^{*}$ \\ * Fakultas Ekonomi dan Bisnis Islam UIN Ar-Raniry \\ a Corresponding author : azimah.dianah@ar-raniry.ac.id \\ b ana.fitria@ar-raniry.ac.id
}

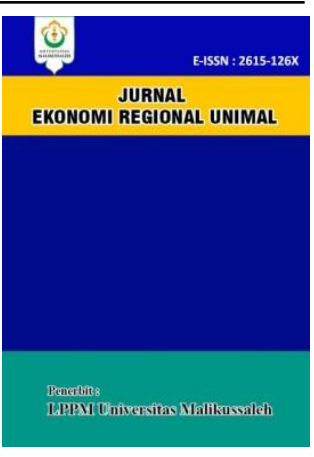

ART I CLE INGORMATION

\section{A B S T R ACT}

\section{Keywords:}

profitability, growth opportunity, net working capital, cash holding.
This research tests the effect of profitability, growth opportunity, and net working capital on corporate cash holding for a sample of banks company listed in Indonesian Stock Exchange over the period 20132015. Population of this research is 31 banks companies at the Indonesian Stock Exchange. This research use path analysis method. Hypothesis test of this research employs standardized multiple regression analysis. The result show that simultaneously profitablity, growth opportunity, and net working capital have influence enough to cash holding. While partially profitability has a positive influence enough to cash holding, growth opportunity and net working capital has a very weak negative effect on cash holding.

\section{PENDAHULUAN}

Bank merupakan lembaga keuangan perantara (intermediary) yang dapat menghimpun dan mengalokasikan dana dari atau kepada masyarakat, serta berfungsi dalam menempatkan dana dan menghimpun dana tersebut yang bertujuan untuk memperoleh keuntungan dan meningkatkan nilai perusahaan dalam batasan tertentu. Salah satu batasannya adalah mencakup tingkat likuiditas.Likuiditas adalah kemampuan suatu perusahaan untuk memenuhi kewajibankewajiban jangka jangka pendeknya (Van Horne \& Wachowicz, 2009:138).Likuiditas bersifat rentan dan dapat secara tiba-tiba terkuras dari suatu bank. Berdasarkan Keynes (1936) terdapat tiga motivasi dalam menahan kas atau untuk mempertahankan likuiditas yaitu untuk hal transaksi, berjaga-jaga, dan spekulasi, dengan kata lain likuiditas erat kaitannya dengan kebijakan penahanan kas.

Kebijakan penahanan kas merupakan kas yang ditahan oleh perusahaan untuk motif berjaga-jaga, transaksi, dan spekulasi (Baker dan
Powell, 2005:165). Kebijakan penahanan kas ini bermanfaat salah satunya adalah untuk menghadapi kesulitan keuangan, kebijakan investasi yang lebih optimal ketika terjadi kesulitan keuangan dan hal-hal yang berhubungan dengan pendanaan. Krisis perbankan yang terjadi selama ini terutama disebabkan oleh krisis likuiditas bank yang menyebabkan terjadinya gagal bayar bank terhadap sebagian besar kewajibannya. Kebijakan penahanan kas akan menghasilkan cadangan likuiditas yang dapat menjadi jaminan atau tindakan berjaga-jaga atas kemungkinan terjadinya kewajiban membayar. Bank yang memiliki kas yang ditahan berlebih dilakukan sebagai sinyal kepada pasar bahwa bank tersebut memiliki likuidtas yang kuat. Namun, kelebihan kas yang ditahan dapat juga diinterpretasikan bahwa bank tersebut lemah dalam hal infrastruktur dalam sistem pembayaran dan pasar uang antar bank (Wuryandani et al,.2014). 
Tabel 1

Lima Perusahaan Perbankan dengan Nilai

Kebijakan Penahanan Kas yang

Berbeda-Beda

\begin{tabular}{|c|l|c|c|c|}
\hline \multirow{2}{*}{ No } & \multicolumn{1}{|c|}{$\begin{array}{c}\text { Nama } \\
\text { Perusahaan }\end{array}$} & \multicolumn{3}{|c|}{$\begin{array}{l}\text { Kas dan Setara Kas Per } \\
\text { Total Aktiva }\end{array}$} \\
\cline { 2 - 5 } 1. Bank & $\begin{array}{l}\text { PT. } \\
\text { Rakyat } \\
\text { Indonesia, Tbk }\end{array}$ & $3,06 \%$ & $2,80 \%$ & $3,28 \%$ \\
\hline 2. & $\begin{array}{l}\text { PT. Bank } \\
\text { Mandiri } \\
\text { (Persero), Tbk }\end{array}$ & $2,60 \%$ & $2,42 \%$ & $2,76 \%$ \\
\hline 3. & $\begin{array}{l}\text { PT. Bank } \\
\text { Tabungan }\end{array}$ & $\begin{array}{l}\text { 2015 } \\
\text { Pensiunan } \\
\text { Nasional, Tbk }\end{array}$ & $1,58 \%$ & $1,67 \%$ \\
\hline 4. & $\begin{array}{l}\text { PT. Bank Mega, } \\
\text { Tbk }\end{array}$ & $2,15 \%$ & $1,91 \%$ & $1,60 \%$ \\
\hline 5. & $\begin{array}{l}\text { PT. Bank } \\
\text { OCBC NISP, } \\
\text { Tbk }\end{array}$ & $1,11 \%$ & $0,96 \%$ & $0,78 \%$ \\
\hline
\end{tabular}

Sumber: data diolah (2019)

Berdasarkan Tabel 1, dapat dilihat pada ke lima perusahaan perbankan yang diambil sebagai sampel awal dari tahun 2013-2015 menunjukkan bahwa jumlah kas dan setara kas pada perusahaanperusahaan tersebut sangat beragam, mulai $0,78 \%$ dari total aktiva sampai dengan 3,28\% dari total aktiva. Dalam kondisi tersebut, perbedaan kas yang ditahan dengan rentang $0,78 \%$ sampai dengan $3,28 \%$ perlu dilakukan analisis terhadap faktor-faktor yang mempengaruhi terjadinya perubahan dan keberagaman nilai dalam menahan kas perusahaan.

Dalam penelitian ini akan diangkat 3 variabel yang diduga berpengaruh terhadap kebijakan penahanan kas yaitu profitabilitas, peluang pertumbuhan, dan modal kerja bersih.

Profitabilitas adalah hasil akhir dari sejumlah kebijakan dan keputusan yang dilakukan oleh perusahaan(Brigham dan Houston, 2009:109). Profitabilitas diduga dapat berpengaruh terhadap kebijakan penahanan kas (Fresard, 2010; Opler et al, 1999; Nguyen, 2005; Ferreira dan Vilela,2004; Decamps dan Villenueuve, 2013). Perusahaan dengan tingkat profitabilitas yang tinggi biasanya memiliki kas yang ditahan tinggi. Ketika perusahaan akan ingin meningkatkan profitabilitasnya dengan jalan berinvestasi cenderung lebih memilih menggunakan kas yang ditahan atau dana internal karena pendanaan internal merupakan pendanaan yang paling murah.Hal ini sejalah dnegan penelitian Fresard (2010) yang menemukan bahwa profitabilitas berpengaruh positif terhadap perusahaan.

Variabel lainnya yang diduga berpengaruh terhadap kebijakan penahanan kas yaitu peluang pertumbuhan (Opler et al., 1999; Kim, Mayer, dan Sherman, 1998; Ferreira dan Vilela., 2004; Ozkan dan Ozkan, 2004; Jinkar, 2013). Peluang pertumbuhan adalah Perusahaan yang mempunyai kemungkinan bertumbuh yang tinggi akan memberikan manfaat yang tinggi di masa depan bagi investor (Scott, 2009:136). Perusahaan yang memiliki peluang pertumbuhan yang tinggi cenderung akan menahan kas yang tinggi pula, hal ini dilakukan agar dapt mengeksekusi peluang tersebut dengan menggunakan pendanaan eksternal (Ferreira dan Filela, 2004).

Selain itu, modal kerja bersih juga diduga dapat mempengaruhi kebijakan penahanan kas (Opler et al., 1999; Afza dan Adnan, 2007; Ogunipe, Ogundipe, dan Ajao, 2012).Modal kerja bersih adalah sejumlah pendanaan jangka panjang yang tersedia untuk membiayai siklus operasi perusahaan setelah perusahaan tersebut selesai mendanai investasi jangka panjangnya yang strategis dalam aset tetap (Hawawini \& Viallet, 2010:84). Modal kerja bersih diduga dapat memberikan pengaruh negatiF terhadap kebijakan penahanan kas semakin besar modal kerja bersih maka akan semakin rendah kas yang ditahan. Hal ini menandakan bahwa perusahaan sedang dalam keadaan defisit modal kerja sehingga diduga perusahaan sedang mengalami krisis likuiditas (Kim, Myers, dan Sherman, 2011).

Pemilihan sektor perbankan yang terdaftar di BEI sebagai obyek penelitian dikarenakan perkembanan kinerja keuangan perbankan yang terdaftar di BEI dapat menjadi pilihan investasi bagi pemilik dana atau calon investor dan kegiatan bank sangat diperlukan bagi lancarnya kegiatan perekonomian di sektor riil. Selain itu berdasarkan hasil survey nasional literasi keuangan pada tahun 2013 sekitar 57\% masyarakat memanfaatkan jasa perbankan namun hanya sekitar 22\% yang memahami apa itu perbankan. Ha inilah yang juga 
menjadi perhatian bagi peneliti untuk meneliti sektor perbankan yang terdaftar di Bursa Efek Indonesia. Selanjutnya terjadinya krisis keuangan pada akhir 2008 yang membawa dampak sulitnya akses pendanaan tak hanya bagi perusahaan keuangan namun juga non keuangan sekali pun yang memaksa setiap sektor untuk memperkuat strategi pendanaan mereka terhadap krisis keuangan yang terjadi. Berdasarkan penelitian Naoki (2012) yang meneliti mengenai kebijakan penahanan kas pada sektor perbankan yang ada di Jepang diketahui bahwa akibat krisis gelobal 2008 bank di Jepang mengalami kesulitan keuangan dalam hal pendanaan dari eksternal. Oleh karena itu kesediaanan kas yang ditahan oleh perusahaan harus ditingkatkan untuk berjaga-jaga sulitnya akses pendanaan dari eksternal, sehingga ketika terjadi kesulitan keuangan perusahaan dapat mengunakan pendanaan yang bersumber dari internal terlebih dahulu.

\section{TINJAUAN TEORITIS Profitabilitas}

Profitabilitas merupakan tingkat keuntungan yang mampu diraih oleh perusahaan pada saat menjalankan operasionalnya dalam hubungannya dengan penjualan, total aktiva maupun modal sendiri (Sartono, 2010:122).Profitabilitas dalam penelitian ini diukur dengan return on asset diduga kan memberikan pengaruh positif atau negatif terhadap kebijakan penahanan kas. Jika dikaitkan dengan salah satu teori penahanan kas pecking order theory, kenaikan profitabilitas akan memberikan pengaruh positif terhadap kebijakan penahanan kas. Berdasarkan pecking order theory tingkat optimal kebijakan penahanan kas dapat ditetapkan dengan menimbang biaya dan manfaat marjinal saat memegang kas. Perusahaan dengan tingkat profitabilitas yang tinggi justru tingkat utangnya rendah, dikarenakan perusahaan yang tingkat profitabilitasnya tinggi memiliki sumber dana internal yang berlimpah. Selanjutnya dalam pecking order theory terdapat urutan sumber dana yang digunakan dalam keputusan pembiayaan perusahaan. Jadi ketika perusahaan membutuhkan dana untuk keperluan inestasi perusahaan dapat memilih untuk menggunakan pendanaan yang dinilai paling murah yaitu pendanaan internal dalam hal ini adalah kas yang ditahan tersebut (Myers, 1984).

Fresard (2010) menemukan bukti bahwa perusahaan yang menahan kas lebih tinggi cenderung akan meningkatkan profitabilitas yang diukur dengan ROA dan kinerja perusahaan yang lebih baik. Hasil penelitian Fresard (2010) menunjukkan bahwa perusahaan yang memiliki pangsa pasar yang besar itu ada karena perusahaan tersebut cenderung memperhatikan tingkat profitabilitas dan penahanan kas yang tinggi.Hal ini dikarenakan perusahaan akan menggunakan laba (profit) yang dimilikinya untuk meningkatkan penahanan kas dalam jumlah yang banyak (Opler et al. 1999). Semakin tinggi tingkat ROA suatu perusahaan maka akan semakin tinggi pula likuiditas asetnya dalam hal ini dapat dikaitkan dengan kebijakan perusahaan dalam menahan kas (Nguyen, 2005).

Sebaliknya jika dilihat dari pengaruh negatif, perusahaan yang memiliki profitabilitas yang rendah cenderung memiliki kas yang rendah pula. Hal ini disebabkan perusahaan lebih menggunakan profit atau keuntungan tersebut untuk membayar utang, sehingga ketika profitabilitas tinggi kas yang ditahan juga akan rendah (Ferreira dan Vilela, 2004).Selanjutnya, ketika profitabilitas melemah atau rendah hal tersebut akan berdampak kepada peningkatan penahanan kas. Hal ini terjadi karena perusahaan akan berjaga-jaga untuk menahan kas lebih banyak namun bukan dari profit tapi dari pendanaan eksternal (Decamps dan Villeneuve, 2013).

\section{Peluang Pertumbuhan}

Peluang pertumbuhan merupakan penentu penting dari kebijakan penahanan kas. Hal ini disebabkan karena dengan memperhatikan kesempatan tumbuh kembangnya suatu perusahaan juga akan membuat perusahaan memperhatikan pendanaan dalam mengeksekusi peluang pertumbuhan tersebut. Dikala perusahaan memiliki peluang pertumbuhan yang tinggi harus didukung oleh segi pendanaan yang tinggi pula. Hal inilah yang menjadikan pengaruh positif 
peluang pertumbuhan terhadap kebijakan penahanan kas (Opler et al., 1999; Kim, Mayer, dan Sherman, 1998; Ferreira dan Vilela., 2004; Ozkan dan Ozkan, 2004; Jinkar, 2013; Arfan et al., 2017). Pada beberapa negara dengan ekonomi yang buruk pendanaan yang berasal dari internal akan sangat bermanfaat digunakan untuk mengeksekusi peluang pertumbuhan ini karena perusahaan ini cenderung sulit untuk mendapatkan pendanaan dari eksternal. Oleh karena itu, kebijakan dalam menahan kas ini sangatlah bermanfaat untuk menyikapi kesempatan tumbuh kembangnya perusahaan Ahrends, Drobetz, dan Puhan (2014).

Perusahaan yang dapat membiayai investasi mereka secara internal akan lebih mudah dalam meraih pangsa pasar tambahan dengan meningkatkan pengeluaran investasi di saat perusahaan yang lain kesulitan dalam mendapatkan pendanaan eksternal yang berupa hutang. Bolton dan Scharfstein (1990), Froot, Scharfstein, danStein (1993), dan Haushalter, klasa, dan Maxwell (2007) menganalisis kebijakan kebijakan penahanan kas sebagai alat untuk menghindari resiko investasi yang menyebabkan hilangnya investasi dan pangsa pasar.

Selain itu tidak selamanya perusahaan yang memiliki peluang pertumbuhan yang tinggi juga memiliki kebijakan penahanan kas yang tinggi, sehingga terdapat pengaruh negatif peluang pertumbuhan terhadap kebijakan penahanan kas (Gill dan Shah, 2012; Afza dan Adnan, 2007; Saddour, 2006).Hal ini disebabkan karena perusahaan dengan peluang pertumbuhan yang tinggi lebih memilih untuk menggunakan pendanaan eksternal untuk berinvestasi daripada menggunakan pendanaan internal.Tipe perusahaan seperti ini merupakan perusahaan yang mudah dalam mendapatkan pendanaan dari eksternal yang berupa utang.Sedangkan menurut Afza dan Adnan (2007) ada sebagian perusahaan yang tetap menahan kas dengan jumlah yang tinggi walaupun tingkat peluang pertumbuhannya sangat rendah. Hal ini terjadi karena beberapa alasan seperti kas yang ditahan tersebut nantinya akan ditahan untuk motif berjaga-jaga jika di masa yang akan datang akan ada peluang pertumbuhan yang menguntungkan. Alasan lainnya jika dikaitkan dengan agency problem yaitu ketika manajer menahan kas yang tinggi agar menghindari mengumpulkan pendanaan dari luar karena dapat menjaga infomasi ini dimanfaatkan oleh investor luar sehingga kesempatan ini akan cenderung digunakan untuk mereka sendiri.

\section{Modal Kerja Bersih}

Modal kerja bersih juga dikenal dengan sebutan lain yaitu working capital (modal kerja). Komponen utama dari modal kerja yaitu piutang, persediaan, kas dan setara kas dan utang.Modal kerja bersih dapat menjadi pengganti uang tunai, oleh karena itu perubahan modal kerja bersih akan mempengaruhi posisi kas. Selain itu, perubahan utang jangka pendek dapat menjadi pengganti uang tunai karena perusahaan mungkin menggunakan utang jangka pendek sebagai sumber daya keuangan (Almeida et.al, 2004).Modal kerja bersihakan memberikan pengaruh positif ataupun negatif terhadap kebijakan penahanan kas. Semakin besar modal kerja bersih maka akan semakin rendah kas yang ditahan. Hal ini membuktikan bahwa perusahaan sedang dalam keadaan difisit modal kerja sehingga diduga perusahaan sedang mengalami krisis likuiditas (opler et al., 1999; Kim, Myer, dan Sherman, 2011).Modal kerja bersih juga diperlukan dalam menjaga kelangsungan aktivitas perusahaan tanpa harus menunggu dari pendapatan atau penerimaan utama perusahaan seperti penjualan sehingga jika perusahaan memiliki modal kerja bersih yang tinggi otomatis akan mengurangi saldo kas mereka (Opler et al., 1999; Afza dan Adnan, 2007; Ogunipe, Ogundipe, dan Ajao, 2012). Selain itu, modal kerja bersih juga dapat mempengaruhi kebijakan penahanan kas secara positif (William dan Fauzi, 2013; Jinkar 2013).Hal semacam ini dapat terjadi dikarenakan dengan adanya kenaikan modal kerja bersih maka nilai asset lancar menjadi tinggi pula dikarenakan kenaikan kebijakan penahanan kas sebagai salah satu komponen asset lancar yaitu kas yang merupakan bagian dari modal kerja bersih. 


\section{Kerangka Konsptual}

Berdasarkan landasan teori dan kajian terhadap penelitian terdahulu, maka disusun suatu kerangka pemikiran teori mengenai penelitian yang akan dilakukan. Kerangka pemikiran teori dapat dilihat pada Gambar 1.

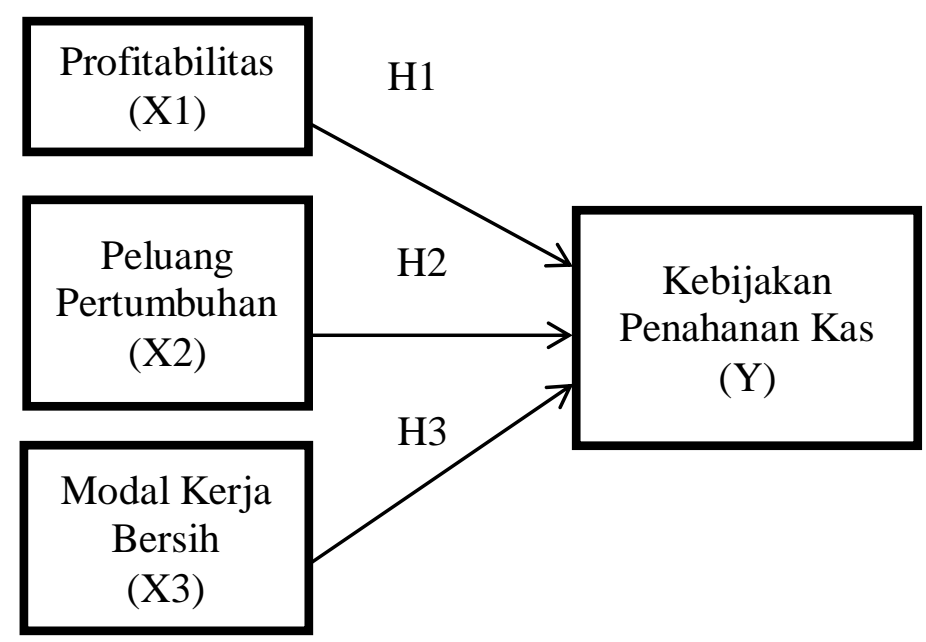

Gambar 1

Kerangka Konseptual

\section{Hipotesis}

Berdasarkan kerangka pemikiran dan perumusan pengujian, yang menjadi hipotesis penelitian ini adalah:

H1 : Diduga profitabilitas berpengaruh negatif dan signifikan terhadap kebijakan penahanan kas.

H2 : Diduga peluang pertumbuhan berpangaruh posistif dan signifikan terhadap kebijakan penahanan kas.

H3 : Diduga modal kerja bersih berpengaruh positif dan signifikan terhadap kebijakan penahanan kas.

\section{METODE PENELITIAN}

Populasi penelitian ini adalah semua perusahaan sektor keuangan perbankan yang telah terdaftar atau go public di BEI dari tahun 2013 samai 2015, serta menerbitkan laporan keuangan per 31 Desember untuk tahun buku 2013-2015. Peneliti memilih perusahaan keuangan sektor perbankan sebagai populasi karena perkembangan kinerja keuangan perbankan yang terdaftar di Bursa Efek Indonesia dapat menjadi pilihan investasi bagi pemilik dana atau calon investor dan kegiatan bank sangat diperlukan bagi lancarnya kegiatan perekonomian di sektor riil. Sektor riil tidak akan dapat berkinerja dengan baik apabila sektor moneter tidak bekerja dengan baik Pemilihan populasi dilakukan dengan mengunakan metode sensus yaitu suatu metode pemilihan populasi yang digunakan untuk meneliti semua elemen yang ada dalam semua wilayah atau sasaran penelitian (Sugiyono, 2004:77). Penentuan populasi selanjutnya dilakukan dengan ketentuan sebagai berikut :

1. Perusahaan yang memiliki data profitabilitas, peluang pertumbuhan, modal kerja bersih, dan kebijakan penahanan kas.

2. Perusahaan perbankan yag terdaftar berturut-turut di BEI tahun 2013-2015.

3. Perusahaan yang tidak memiliki nilai ekuitas negatif.

Proses penentuan populasi dapat dilihat pada Tabel 2

Tabel 2

Proses Penentuan Populasi Penelitian

\begin{tabular}{|c|c|}
\hline $\begin{array}{l}\text { KRITERIA } \\
\text { POPULASI } \\
\end{array}$ & $\begin{array}{c}\text { JUMLAH } \\
\text { PERUSAHAAN }\end{array}$ \\
\hline $\begin{array}{ll}\text { a. } & \text { Perusahaan } \\
& \text { perbankanyang } \\
& \text { terdaftar di BEI } \\
& \text { tahun } \quad \text { 2013- } \\
& \text { 2015berturut turut. } \\
\text { b. } & \text { Perusahaan } \\
& \text { perbankan yang } \\
& \text { memiliki nilai }\end{array}$ & 33 \\
\hline $\begin{array}{l}\text { ekuitas negatif dan } \\
\text { data tidak lengkap }\end{array}$ & (2) \\
\hline $\begin{array}{l}\text { Total Populasi } \\
\text { Sasaran }\end{array}$ & 31 \\
\hline
\end{tabular}

Sumber Olahan Penulis, (2019)

\section{Jenis Data dan Teknik Pengumpulan Data}

Data yang digunakan dalam penelitian ini adalah data sekunder yang berupa data kuantitatif yang diukur dalam skala numerik yang dapat diperoleh dari internal dan eksternal organisasi, penulusuran dokumen, atau publikasi informasi (Sekaran, 2007:65).Dalam studi ini data sekunder yang digunakan berasal dari laporan keuangan perusahaan sektor perbankan yang terdaftar di BEI yang dipublikasi.Data yang digunakan meliputi total kas dan setara kas, total aktiva, harga pasar ekuitas, nilai buku ekuitas, total aktiva lancar, total hutang lancar, dan laba bersih setelah pajak. 
Sumber data yang digunakan dalam penelitian ini diperoleh dari laporan keuangan perusahaan sektor perbankan yang terdaftar di Bursa Efek Indonesia selama periode tahun 2013-2015 dan data ICMD (Indonesia Capital Market Directory).Alasan dipilihnya periode waktu 2013-2015 karena merupakan data terbaru yang dapat mencerminkan keadaan perusahaan perbankan saat ini.

Teknik pengumpulan data dalam penelitian ini dilakukan melalui cara dokumentasi yaitu pengumpulan data yang didasarkan pada catatan yang telah tersedia di BEI. Data ini diperoleh dari Indonesian Capital Market Directory (ICMD) dan situs resmi Bursa Efek Indonesia ((BEI) di www.idx.co.id.Pada penelitian ini peneliti menggunakan balanced pooled data atau balanced panel data. Panel data adalah gabungan dari data time series (antar waktu) dan data cross section (antar individu/ruang). Untuk menggambarkan panel data secara singkat, misalkan pada data cross section, nilai dari satu variabel atau lebih dikumpulkan untuk beberapa unit sampel pada suatu waktu. Dalam panel data, unit cross section yang sama disurvei dalam beberapa waktu (Gujarati, 2003:637). balanced panel data adalah pengamatan setiap periode memiliki jumlah unit analisis yang selalu sama.

\section{Definisi Operasional Variabel}

\section{Variabel Dependen (Y)}

Variabel dependen dalam penelitian ini adalah kebijakan penahanan kas. Kebijakan penahanan kas merupakan sejumlah uang yang ditahan dalam kas untuk rencana-rencana atau spekulasi, didepositokan atau ditabung di Bank, dan dibelikan valuta asing atau surat berharga (Gilarso T, 2008:227). Variabel kebijakan penahanan kasmenggunakan skala rasio. Pengukuran yang digunakan yaitu (Opler et al., 1999):

Penahanan Kas $=\frac{\text { Kas dan Setara Kas }}{\text { Total Aktiva }} \times 100 \%$

\section{Variabel Independen $(\mathbf{X})$}

Variabel independen dalam penelitian ini adalah profitabilitas, peluang pertumbuhan, dan modal kerja bersih.

\section{Profitabilitas}

Profitabilitas adalah hasil akhir dari sejumlah kebijakan dan keputusan yang dilakukan oleh perusahaan(Brigham dan Houston, 2009:109).Variabel profitabilitasmenggunakan skala rasio. Pengukuran yang digunakan yaitu:

$$
R O A=\frac{\text { Laba bersih setelah pajak }}{\text { Total Aktiva }} \times 100 \%
$$

\section{Peluang pertumbuhan}

Peluang pertumbuhan adalah prospek pertumbuhan perusahaan di masa depan, perusahaan yang mempunyai kemungkinan bertumbuh yang tinggi akan memberikan manfaat yang tinggi dimasa depan bagi investor (Scott, 2009:136). Variabel peluang pertumbuhan menggunakan skala rasio. Pengukuran yang digunakan yaitu (Booth, et al., 2001):

$$
\begin{aligned}
& \text { Price Book Value (PBV) } \\
& =\frac{\text { Harga Pasar per Lembar Saham }}{\text { Nilai Buku per Lembar Saham }} \times 100 \%
\end{aligned}
$$

\section{Modal kerja bersih}

Modal kerja bersih merupakan selisih antara aktiva lancar dan kewajiban lancar, menyediakan gambaran yang sangat berguna dalam menentukan kebijaksanaan pembiayaan jangka pendek (Brealey, Myers, dan Marcus ,2008:139). Variabel Modal kerja bersihmenggunakan skala rasio. Pengukuran yang digunakan yaitu (Ferreira dan Vilela, 2004):

$$
\begin{aligned}
& \text { Modal Kerja Bersih } \\
& =\frac{\text { Aktiva Lancar }- \text { Utang Lancar }}{\text { Total Aktiva }} \times 100 \%
\end{aligned}
$$

\section{HASIL PENELITIAN DAN PEMBAHASAN}

\section{Hasil Pengujian Hipotesis}

Pengujian pengaruh profitabilitas $\left(X_{1}\right)$, profitabilitas $\left(X_{2}\right)$, peluang pertumbuhan $\left(X_{3}\right)$, dan modal kerja bersih $\left(X_{4}\right)$ terhadap kebijakan penahanan kas (Y) dilakukan dengan menggunakan analisis regresi berganda yang distandarkan atau analisis jalur. Berhubung penelitian ini menggunakan metode sensus, maka 
untuk pengujian hipotesis tidak dilakukan uji signifikansi, baik uji-t (untuk pengaruh secara parsial) maupun uji-F (untuk pengaruh secara bersama-sama).Analisis jalur digunakan untuk mendapatkan nilai-nilai koefisien jalur dan koefisien determinasi yang sesungguhnya.

Koefisien jalur digunakan untuk menguji pengaruh variabel independen secara parsial terhadap variabel dependen, sedangkan untuk mengetahui besar atau kuat-lemahnya pengaruh variabel independen terhadap variabel dependen, baik secara bersama-sama maupun secara parsial ditunjukkan oleh koefisien determinasi.Nilai koefisien determinasi digunakan untuk mengetahui seberapa besar (dalam persen) variasi dalam variabel dependen mampu dijelaskan, baik secara bersama-sama maupun secara parsial oleh variabel independen.

Berdasarkan hasil perhitungan dengan menggunakan bantuan program SPSS versi 17.0, hasil analisis jalur pengaruh profitabilitas $\left(X_{1}\right)$, profitabilitas $\left(X_{2}\right)$, peluang pertumbuhan $\left(X_{3}\right)$, dan modal kerja bersih $\left(X_{4}\right)$ terhadap kebijakan penahanan kas (Y)

Berdasarkan hasil pengujian,nilai $\rho_{Y X}$ dari ketiga variabel independen, yaitu profitabilitas, peluang pertumbuhan, dan modal kerja bersih menunjukkan hasil bahwa semua $\rho_{Y X_{i}}$ $\neq 0$, dimana $\rho_{Y X_{1}}=0,412, \rho_{Y X_{2}}=-0,088$, dan $\rho_{Y X_{3}}=$ -0,092.Seperti diketahui bahwa syarat untuk menyatakan bahwa variabel independen secara bersama-sama berpengaruh terhadap variabel dependen apabila sedikit atau sekurang-kurangnya ada satu $\rho_{Y X_{i}} \neq 0$. Berdasarkan syarat tersebut, hasil penelitian ini menolak $\mathrm{H}_{0}$ (hipotesis nol) dan menerima $\mathrm{H}_{\mathrm{a}}$ (hipotesis alternatif).Sehingga dapat dikatakan bahwa profitabilitas, peluang pertumbuhan, dan modal kerja bersihsecara bersama-sama berpengaruh terhadap kebijakan penahanan kas.

Nilai koefisien determinasi sebesar 0,141 menunjukkan bahwa profitabilitas, peluang pertumbuhan, dan modal kerja bersihsecara bersama-sama berpengaruh terhadap kebijakan penahanan kas sebesar $14 \%$, sedangkan sisanya sebesar $86 \%$ dipengaruhi oleh variabel-variabel lain yang tidak dimasukkan dalam model penelitian ini $(\varepsilon)$.

\section{Tabel 3}

Koefisien Determinasi

Model Summary ${ }^{b}$

\begin{tabular}{|l|c|r|r|r|r|}
\hline Model & $\mathrm{R}$ & $\begin{array}{c}\mathrm{R} \\
\text { Square }\end{array}$ & $\begin{array}{c}\text { Adjusted R } \\
\text { Square }\end{array}$ & $\begin{array}{c}\text { Std. Error of } \\
\text { the Estimate }\end{array}$ & $\begin{array}{l}\text { Durbin- } \\
\text { Watson }\end{array}$ \\
\hline 1 & $.376^{\mathrm{a}}$ & .141 & .112 & .015537 & 2.015 \\
\hline
\end{tabular}

a. Predictors: (Constant), Modal kerja bersih, Peluang pertumbuhan, Profitabilitas

b. Dependent Variable: Kebijakan

penahanan kas

\section{Pembahasan}

Pengaruh Profitabilitas, Peluang pertumbuhan, dan Modal kerja bersih, Terhadap Kebijakan Penahanan Kas

Berdasarkan hasil pengujian hipotesis, hasil penelitian ini menunjukkan bahwa peluang pertumbuhan, profitabilitas, modal kerja bersih, dan pembayaran utang pemerintah berpengaruh terhadap kebijakan penahanan kas yang ditandai oleh semua nilai $\rho_{Y X}$ tidak sama dengan nol ( $\rho_{Y X_{i}}$ $\neq 0$ ). Selanjutnya, nilai koefisien determinasi sebesar 0,141 menunjukkan bahwa peluang pertumbuhan, profitabilitas, modal kerja bersih, dan pembayaran utang pemerintah secara bersama-sama berpengaruh terhadap kebijakan penahanan kas sebesar 14\%, sedangkan sisanya sebesar $86 \%$ dipengaruhi oleh variabel-variabel lain yang tidak dimasukkan dalam penelitian ini $(\varepsilon)$.

Mengacu kepada klasifikasi Sarwono (2007:35), maka pengaruh sebesar 14\% tersebut menunjukkan bahwa peluang pertumbuhan, profitabilitas,dan modal kerja bersihsecara bersama-sama memiliki pengaruh yang cukup terhadap kebijakan penahanan kas pada perusahaan sektor perbankan yan terdaftar di Bursa Efek Indonesia. Pengaruh yang cukup pada peluang pertumbuhan, profitabilitas, dan modal kerja bersih, secara bersama-sama dalam menjelaskan variasi dalam kebijakan penahanan kas dapat disebabkan karena masih banyaknya variabel-variabel lain yang tidak dimasukkan dalam model penelitian ini yang berperan dalam menjelaskan variasi dalam kebijakan penahanan 
kas pada perusahaan sektor perbankan yan terdaftar di Bursa Efek Indonesia.

\section{Pengaruh Profitabilitas Terhadap Kebijakan penahanan kas}

Berdasarkan hasil pengujian hipotesis, hasil penelitian ini menunjukkan bahwa profitabilitas berpengaruh positif terhadap kebijakan penahanan kas dengan ditandai oleh nilai koefisien jalur sebesar 0,412 dan nilai koefisien determinasi sebesar $0,169744 \%$. Nilai koefisien determinasi sebesar 0,169744\% menunjukkan bahwa profitabilitas berpengaruh positif terhadap kebijakan penahanan kas sebesar 0,169744\%.

Pengaruh positif profitabilitas terhadap kebijakan penahanan kas menunjukkan bahwa hasil penelitian ini konsisten dengan hasil penelitian Fresard (2010) menemukan bukti bahwa perusahaan yang menahan kas lebih tinggi cenderung akan meningkatkan profitabilitas perusahaan dan kinerja perusahaan yang lebih baik. Hasil penelitian Fresard (2010) menunjukkan bahwa perusahaan yang memiliki pangsa pasar yang besar itu ada karena perusahaan tersebut cenderung memperhatikan tingkat profitabilitas dan penahanan kas yang tinggi. Hal ini dikarenakan perusahaan akan menggunakan laba (profit) yang dimilikinya untuk meningkatkan penahanan kas dalam jumlah yang banyak (Opler et al. 1999). Semakin tinggi tingkat profitabilitas suatu perusahaan maka akan semakin tinggi pula likuiditas asetnya atau sebaliknya dalam hal ini dapat dikaitkan dengan kebijakan perusahaan dalam menahan kas (Nguyen,2005).

Pengaruh sebesar 0,169744\% profitabilitas terhadap kebijakan penahanan kas menunjukkan bahwa variasi dalam kebijakan penahanan kas mampu dijelaskan oleh profitabilitas sebesar $0,169744 \%$. Mengacu kepada klasifikasi sarwono (2007:35), maka pengaruh sebesar 0,169744\% tersebut menunjukkan bahwa profitabilitas secara parsial memiliki pengaruh positif yang kuat terhadap kebijakan penahanan kas pada perusahaan sektor perbankan yang terdaftar di BEI.

\section{Pengaruh Peluang Pertumbuhan Terhadap Kebijakan Penahanan Kas}

Berdasarkan hasil pengujian hipotesis, hasil penelitian ini menunjukkan bahwa peluang pertumbuhan berpengaruh negatif terhadap kebijakan penahanan kas dengan ditandai oleh nilai koefisien jalur sebesar $-0,088$ dan nilai koefisien determinasi sebesar0,007744\%. Nilai koefisien determinasi sebesar 0,007744\% menunjukkan bahwa peluang pertumbuhan berpengaruh positif terhadap kebijakan penahanan kas sebesar 0,007744\%.

Pengaruh positifpeluang pertumbuhan terhadap kebijakan penahanan kas menunjukkan bahwa hasil penelitian ini konsisten dengan hasil penelitian yang telah dilakukan oleh Gill dan Shah (2012); Afza dan Adnan (2007); Saddour (2006); Arfan et al., (2017). Perusahaan dengan peluang pertumbuhan yang tinggi tidak selamanya akan melakukan penahanan kas yang tinggi pula. Hal ini dapat disebabkan perusahaan yang memiliki peluan pertumbuhan yang tinggi akan cenderung memilih menggunakan pendanaan eksternal untuk berinvestasi. Perusahaan sepeti ini merupakan perusahaan dengan tipe yang mudah dalam hal mendapatkan akses pendanaan dari pihak eksternal. Namun, ada juga perusahaan yang akan menahan kas yang tinngi walaupun peluang pertumbuhannya kecil (Afza dan Adnan, 2007). Hal ini terjadi karena adanya motif berjaga-jaga jika dimasa yang akan datang akan ada peluang pertumbuhan yang mengntungkan sehingga dapat langsun menggunakan kas yang sudah ditahan tersebut.

Pengaruh sebesar $0,007744 \%$ peluang pertumbuhan terhadap kebijakan penahanan kas menunjukkan bahwa variasi dalam kebijakan penahanan kas mampu dijelaskan oleh peluang pertumbuhan sebesar 0,007744 \%.Mengacu kepada klasifikasi sarwono (2007:35), maka pengaruh sebesar $0,007744 \%$ tersebut menunjukkan bahwa peluang pertumbuhan secara parsial memiliki pengaruh negatif yang sangat lemah terhadap kebijakan penahanan kas pada perusahaan sektor perbankan yang terdaftar di BEI. 


\section{Pengaruh Modal Kerja Bersih Terhadap Kebijakan Penahanan Kas}

Berdasarkan hasil pengujian hipotesis, hasil penelitian ini menunjukkan bahwa modal kerja bersih berpengaruh negatif terhadap kebijakan penahanan kas dengan ditandai oleh nilai koefisien jalur sebesar -0,092 dan nilai koefisien determinasi sebesar 0,008464\%.Nilai koefisien determinasi sebesar 0,008464\% menunjukkan bahwa modal kerja bersih berpengaruh negatif terhadap kebijakan penahanan kas sebesar 0,008464\%.

Pengaruh negatif modal kerja bersih terhadap kebijakan penahanan kas menunjukkan bahwa hasil penelitianini konsisten dengan hasil penelitian Ogundipe, Ogundipe, dan Ajao (2012); Afza dan Adnan (2007); Opler et al (1999). Modal kerja bersih merupakan substitusi dari kebijakan penahanan kas yang artinya adalah ketika modal kerja bersih rendah secara otomatis akan menaikkan kas yang ditahan. Hal ini disebabkan karena kemudahan untuk mengubahnya kedalam bentuk kas saat perusahaan membutuhkannya. Sebagai contoh, piutang dapat dengan mudah dicairkan melalui proses sekuritisasi, hutang bank juga bisa dengan mudah diubah menjadi kas. Jadi modal kerja bersih bisa dianggap sebagai substitusi dari kebijakan penahanan kas.

Pengaruh sebesar 0,008464\% modal kerja bersih terhadap kebijakan penahanan kas menunjukkan bahwa variasi dalam kebijakan penahanan kas mampu dijelaskan oleh modal kerja bersih sebesar $0,008464 \%$. Mengacu kepada klasifikasi sarwono (2007:35), maka pengaruh sebesar 0,008464\% tersebut menunjukkan bahwa modal kerja bersih secara parsial memiliki pengaruh negatif yang sangat lemah terhadap kebijakan penahanan kas pada perusahaan sektor perbankan yang terdaftar di BEI.

\section{KESIMPULAN DAN SARAN Kesimpulan}

1. Profitabilitas, peluang pertumbuhan dan modal kerja bersih secara bersama-sama atau juga secara simultan dapat dikatakan bahwa memiliki pengaruh yang cukup terhadap kebijakan penahanan kas pada perusahaan sektor perbankan yang terdaftar di Bursa Efek Indonesia.

2. Profitabilitas secara parsial juga memiliki pengaruh yang positif yang cukup terhadap kebijakan penahanan kas yang artinya bahwa semakin tinggi profitabilitas pada sektor perbankan juga berarti semakin tingginya kebijakan penahanan kas.

3. Peluang pertumbuhan secara parsial juga memiliki pengaruh yang negatif yang sangat lemah terhadap kebijakan penahanan kas yang artinya bahwa semakin tinggi peluang pertumbuhan pada sektor perbankan juga berarti semakin rendahkebijakan penahanan kas.

4. Modal kerja bersih secara parsial juga memiliki pengaruh yang negatif yang sangat lemah terhadap kebijakan penahanan kas yang artinya bahwa semakin tinggi modal kerja bersih pada sektor perbankanjuga berarti semakin rendah kebijakan penahanan kas.

\section{Saran}

1. Variabel independen yang teliti hanya terdiri dari tiga variabel independen yaitu profitabilitas, peluang pertumbuhan, dan modal kerja bersih yang memiliki pengaruh hanya sebesar $14 \%$ sedangkan sisanya sebesar $86 \%$ dipengaruhi oleh variabel lainnya yang tidak dimasukkan dalam penelitian ini. Oleh karena itu masih banyak variabel lainnya yang diduga akan memepengaruhi kebijakan penahanan kas pada sektor perbankan yang terdaftar di Bursa Efek Indonesia.

2. Penelitian ini diharapkan dapat membantu pihak sektor perbankan dalam menjalankan kebijakan penahanan kas limit dalam melaksanakan fungsi ALCO (asset dan Liability Committee) untuk mengatur tingkat bunga dalam usahanya 


\section{DAFTAR PUSTAKA}

Afza, T.\& Sh. Muhammad Adnan. (2007). Determinants Of Corporate Cash Holdings: A Case Study Of Pakistan. Proceedings of Singapore Economic Review Conference (SERC) 2007, August 01-04, Organized by Singapore Economics Review \&The University of Manchester (Brooks World Poverty Institute). Singapore.164-165.

Ahrends, M., Drobetz, W., \& Puhan, T.,X, (2015). Cyclicality of Growth Opportunities and the Value of Cash Holdings. SSRN Journals, 1-67.

Almeida, H., M. Campello, \& M. Weisbach. (2004). TheCash Flow Sensitivity of Cash, Journal of Finance, 59:1777-1804.

Arfan, M., Basri, H., Handayani, R., Majid, M.S.A., Fahlevi, H., Dianah, A. (2017).Determinats of Cash Holdingof Listed Manufacturing Companies in Indonesian Stock Exchange. $D L S U$ Bussines Economic and Review, 26(2): 112.

Baker, H. Kent \& Gary E. Powell.(2005). Understanding Financial Management: A Practical Guide. United Kingdom: Blackwell Publishing Ltd.

Bolton, Patrick, \& David Scharfstein, (1990), A theory of predation based on agency problems in financial contracting, American Economic Review, 93-106.

Booth, Laurence, Varouj Aivazian, DemirgucKunt \& Vojislav Maksimovic. (2001). Capital Structure in Developing Countries.The Journal of Finance.LVI(1): 87-130.

Brealey, Richard A., Stewart C. Myers, \& Alan J. Marcus. (2008). Principles of Corporate Finance. New York: McGraw-Hill, Inc.

Brigham, Eugene F. \& Joel F. Houston.(2009). Fundamental of Financial Management. Orlando: Harcourt College Publishers.

Decamps, J. P. \& Villeneuve, S..(2013). Corporate cash policy with liquidity and profitabilityrisks. Working Paper. Retreived fromwww.eea-esem.com/files/papers/eeaesem/2013/988/DV_130213.pdf

Ferreira, Miguel A., \& Antonio S Vilela.(2004). Why Do Firms hold Cash? Evidence from EMU Countries.European Financial Management, 10(2): 295-319.

Fresard, L. (2010). Financial strength and product market behavior: The real effects of corporate cash holding. The Journal of Finance, 65(3), 1097-1122.

Froot, Kenneth, David Scharfstein, and Jeremy Stein.(1993). Risk management: coordinating corporate investment and financing policies. Journal of Finance, 48:1629-1658.

Gilarso.T. (2008).Pengantar Ilmu Ekonomi Makro. Yogyakarta: Kanisius.

Gill, Amarjit \& Charul Shah.(2012). Determinants of Corporate Cash Holdings: Evidence from Canada. International Journal of Economics \& Finance, 4(1):70-79.

Guilford, J.P. (1956). Fundamental Statistic in Psychology and Education.3rd Ed.

New York: McGraw-Hill Book Company, Inc.

Gujarati, Damodar N. (2003). Basic Econometric 4th Edition. Singapore: McGraww-Hill.

Haushalter, David, Sandy Klasa, and William Maxwell. (2007). The influence of product market dynamics on a firm's cash holdings and hedging behavior.Journal of Financial Economics, 84:797-825.

Hawawini, Gabriel \& Viallet Claude. (2010). Finance For Excutives Managing For Value Creation. South-Western: Cengage Learning.

Jinkar, R., T. (2013).Analisa Faktor-Faktor Penentu kebijakan Cash Holding Perusahaan Manufaktur di Indonesia.Mini Economica, 42: 129-146.

Keynes, J.M. (1936). The General Theory of Employment, In: Interest \& Money. London: Harcourt Brace. 
Kim, Chang Jhin, David. C. Mayer,\& Ann. E. Sherman. (1998). The Determinants of Corporate Liquidity: Theory And Evidence. Journal of Financial \& Quantitative Analysis, 33: 335-359.

Myers, Stewarts C. (1984). The Capital Structure Puzzle.Journal of Finance, 39: 572- 592.

Naoki, Shinada. (2012). Firm's Cash Holdings and Performance Evidence From Japanese Corporate Finance. The Resaerch Institute of Economy, Trade and Industry, Series 12E-031, 1-35.

Nguyen, P. (2005). How sensitive are Japanese firms to earnings risk? Evidence from cash holdings".School of Banking \& Finance University of New South Wales, 1-41.

Ogundipe, Lawrencia Olatunde, Sunday Emanuel Ogundipe.\& Samuel Kehinde Ajao.(2012). Cash Holding and Firm Characteristic: Evidence From Nigerian Emerging Market. Journal of Business, Economic \& Finance, 1:45-57.

Opler, Tim, Pinkowitz Lee, Rene Stulz., \& Rohan Williamson.(1999). The Determinants and Implications Of Corporate Cash Holdings. Journal of financial Economics, 52: 3-46.

Ozkan, Aydin, \& Neslihan Ozkan.(2004). Corporate Cash Holdings: An Empirical Investigation of UK Companies. Journal of Banking \& Finance, 28: 2103-2134.

Priyatno, Duwi. (2010). Teknik Mudah dan Cepat Melakukan Analisis Data Penelitian Dengan SPSS. Yogyakarta: Gava Media.

Saddour, Khaoula. (2006). The Determinants and The Value of Cash Holding: Evidence from French firms. Centre de Recherces sur la Gestion, 2-33.

Sartono, Agus. (2010). Manajemen Keuangan; Aplikasi dan Teori. Yogyakarta: BPFEYogyakarta.

Sarwono, Jonathan. (2007). Analisis Jalur untuk Riset Bisnis dengan SPSS.Yogyakarta : Andi Offset.
Scott, William R. (2009). Financial Accounting Theory, 5th Ed. Toronto: Prentice-Hall.

Sekaran, Uma. (2007). Research Methods for Business: A Skill Building Approach. New York: John Wiley \& Sons.

Sugiyono. (2004). Metode Penelitian Bisnis. Bandung :Alfabeta.

Van Horne, James C. \& John M. Wachowicz. (2008). Fundamentals of Financial Management, (13th Ed).New Jersey:Prentice Hall.

Wuryandani, G., Ginting, R., Dudy, I., \& Zulkarnain, S. (2014). Pengelolaan Dana dan Likuiditas Bank.Buletin Ekonomi Moneter dan Perbankan.(Januari), 247-276. 